\author{
В.В. Бережнная, Р.В. Тимочинов, \\ Е.Ж. Кушаева, А.Г. Клыков
}

\title{
ПЛОДОРОДИЕ ПОЧВЫ И УРОЖАЙНОСТЬ ЯРОВОЙ ПШЕНИЦЫ В ЗАВИСИМОСТИ ОТ РАЗНЫХ СИСТЕМ УДОБРЕНИЙ
}

Основная задача современной системы земледелия - получение стабильных и высоких урожаев. Получать высокую урожайность яровой пшеницы хорошего качества в условиях Приморского края в последние годы достаточно сложно, поэтому вопрос увеличения урожайности яровой пшеницы является актуальным. В решении этого вопроса важная роль отводится агротехническим приемам способствующим повышению плодородия почвы и поддержание его на должном уровне. При этом главная роль принадлежит научно обоснованной системе применения удобрений [Моисеенко, 2006], которая существенно влияет на плодородие и свойства почвы, что в свою очередь определяет величину будущего урожая и качество возделываемой продукции [Дмитриев, 2015; Гамзиков, 2016].

Большинство земель, используемых в сельскохозяйственном производстве Приморского края, имеют низкое плодородие и нуждаются в дополнительном внесении элементов питания. Систематическое применение в севооборотах органических, минеральных удобрений и известкования изменяет всю совокупность агрохимических свойств почвы: снижается кислотность, количество подвижных форм питательных веществ, степень их подвижности и доступность для растений [Грицун, 1964; Федоров, 1998; Моисеенко, 2006].

Плодородие почвы можно оценить с использованием агрохимических показателей. Детальный обзор разработок в этом направлении, сделан ведущими агрохимиками страны Д.Н. Прянишниковым, Л.М. Державиным и А.С. Фридом. В качестве основных методов оценки авторы рассматривают расчет «относительного балла плодородия, ОБП», предложенный центральным научно - исследовательским институтом агрохимического обслуживания, (ЦИНАО). Этим методом оценивают кислотность почв, содержание гумуса, фосфора, калия, кальция, магния, основных микроэлементов, сумму поглощенных оснований и степень насыщенности почв основаниями. Расчет «со- 
вокупного почвенного балла, СПБ», разработанного государственным институтом земельных ресурсов, (ГИЗР). В основу расчета положены материалы ГИЗР, которые предусматривают определение совокупного почвенного балла относительно возделываемых сельскохозяйственных культур и балла нормативной урожайности. При этом оценивают следующие показатели качества почв: содержание гумуса в пахотном слое почвы, \%; мощность гумусового горизонта, см; запасы гумуса в гумусовом горизонте, т/га; сумма поглощенных оснований, мэкв на 100 г почвы; содержание физической глины в пахотном слое, \%; кислотность почвы (значение $\mathrm{pH}$ ). Кулаковской и др. [Гаврилюк, 1971; Гаврилюк, 1972] для характеристики плодородия используют относительный индекс комплекса агрохимических свойств (pH, фосфор, калий, гумус) в качестве индекса окультуренности как среднеарифметическую величину относительных индексов используемых показателей. Э.П. Синельниковым, и Ю.И. Слабко для Приморского края предложена оценка почвенного плодородия, при помощи «комплексного агрохимического показателя» (КАП), с учетом значений интегральных показателей всех основных свойств почвы [Синельников, 2005; Синельников, 2013; Державин, 2001].

Оценка плодородия почвы на пахотных землях является заключительным этапом почвенно-агрохимического обследования [Слабко, 2018] и является самым важным и актуальным моментом любого почвенноагрохимического исследования [Синельников, 2005].

Цель исследований - определить влияние плодородия почвы на урожайность и качество зерна яровой пшеницы. Для достижения поставленной цели решались следующие задачи:

- установить влияние различных систем удобрений на содержание основных элементов питания в растении, морфологических и биохимических показателей;

- изучить влияние плодородия почвы на урожайность и качество зерна яровой пшеницы.

Исследования выполнялись на агрохимическом стационаре в ФГБНУ «ФНЦ агробиотехнологий Дальнего Востока им. А.К. Чайки» (г. Уссурийск, п. Тимирязевский), заложенным в 1941 году на лугово-бурой отбеленной почве. В работе использовали комплексную оценку агрохимических показателей: определение подвижных фосфора и калия по методу Кирсанова; легкогидролизуемого азота по методу Тюрина и Кононовой; органического веще- 
ства по методу Тюрина; гидролитической кисолотности и суммы поглощен-

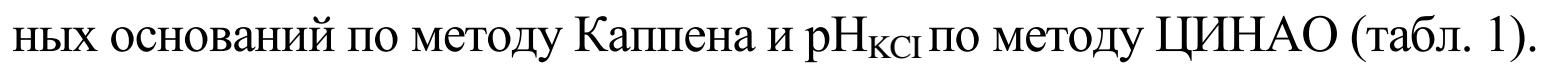

Таблийа 1

Агрохимические показатели почвы стационара ФГБНУ «ФНЦ агробиотехнологий Дальнего Востока им. А.К. Чайки»

\begin{tabular}{|c|c|c|c|c|c|c|c|}
\hline Вариант & $\begin{array}{l}\mathrm{P}_{2} \mathrm{O}_{5} \\
\mathrm{M \Gamma} / \mathrm{K} \Gamma\end{array}$ & $\begin{array}{l}\mathrm{K}_{2} \mathrm{O} \\
\mathrm{M \Gamma} / \mathrm{K} \Gamma\end{array}$ & $\begin{array}{c}\mathrm{N} \\
\text { л.г., } \\
\text { мг/кг }\end{array}$ & $\begin{array}{l}\mathrm{pH}_{\mathrm{KCl}} \\
\text { ед. }\end{array}$ & $\begin{array}{c}\text { Органиче- } \\
\text { ское ве- } \\
\text { щество, \% }\end{array}$ & $\begin{array}{c}\mathrm{S}, \\
\text { мэкв/ } \\
100 г\end{array}$ & $\begin{array}{c}\text { Нг, } \\
\text { мЭКв/ } \\
100 г\end{array}$ \\
\hline \multicolumn{8}{|c|}{ Последействие удобрений } \\
\hline $\begin{array}{c}\text { Контроль } \\
\text { (без удобрений) }\end{array}$ & 29 & 121 & 73 & 5,1 & 2,63 & 15,8 & 5,98 \\
\hline $\mathrm{H}_{260}+\mathrm{H}_{9}$ & 39 & 128 & 70 & 5,6 & 2,86 & 18,6 & 2,74 \\
\hline $\mathrm{H}_{260}+\mathrm{U}_{9}+\mathrm{N}_{2750} \mathrm{P}_{2760} \mathrm{~K}_{1635}$ & 166 & 184 & 67 & 5,6 & 2,67 & 18,6 & 2,86 \\
\hline $\mathrm{H}_{420}+\mathrm{U}_{9}+\mathrm{N}_{2138} \mathrm{P}_{4110} \mathrm{~K}_{1570}$ & 190 & 205 & 73 & 5,5 & 2,88 & 17,8 & 2,52 \\
\hline \multicolumn{8}{|c|}{ Действие удобрений } \\
\hline $\begin{array}{c}\text { Контроль } \\
\text { (без удобрений) }\end{array}$ & 10 & 89 & 70 & 4,6 & 2,77 & 19,0 & 6,97 \\
\hline $\begin{array}{l}\mathrm{H}_{220}+\mathrm{U}_{22}+\mathrm{N}_{1033} \mathrm{P}_{1410} \mathrm{~K}_{1125} \\
+ \text { под пшеницу } \mathrm{N}_{30} \mathrm{P}_{45} \mathrm{~K}_{45}\end{array}$ & 34 & 121 & 80 & 5,4 & 3,08 & 20,8 & 3,71 \\
\hline $\begin{array}{c}\mathrm{H}_{220}+\mathrm{U}_{22}+\mathrm{N}_{2633} \mathrm{P}_{2780} \mathrm{~K}_{2153} \\
+ \text { под пшеницу } \mathrm{N}_{60} \mathrm{P}_{90} \mathrm{~K}_{90}\end{array}$ & 58 & 198 & 102 & 5,4 & 3,76 & 21 & 3,79 \\
\hline $\begin{array}{c}\mathrm{U}_{30}+\mathrm{N}_{1055} \mathrm{P}_{1270} \mathrm{~K}_{985} \\
+ \text { под пшеницу } \mathrm{N}_{30} \mathrm{P}_{45} \mathrm{~K}_{45}\end{array}$ & 29 & 108 & 78 & 5,0 & 3,55 & 17,6 & 5,14 \\
\hline $\begin{array}{c}\mathrm{N}_{2620} \mathrm{P}_{2855} \mathrm{~K}_{2100} \\
+ \text { +под пшеницу } \mathrm{N}_{60} \mathrm{P}_{90} \mathrm{~K}_{90}\end{array}$ & 20 & 160 & 78 & 4,5 & 3,41 & 13,6 & 5,37 \\
\hline
\end{tabular}

Комплексная оценка (КАП) позволяет разделить уровень агрохимического состояния почвы по величине КАП на «очень низкое» $(<20$ баллов), «низкое» (21-40), «удовлетворительное» (41-60), «хорошее» (61-80) и «высокое» (>80 баллов) [Синельников, 2005; СТП 2529001383-96].

В качестве объекта исследований взят районированный сорт яровой пшеницы (Triticum aestivum L.) Приморская 39. Посев оригинальными семенами проводился 7 апреля рядовым способом с нормой высева 5,5 млн.

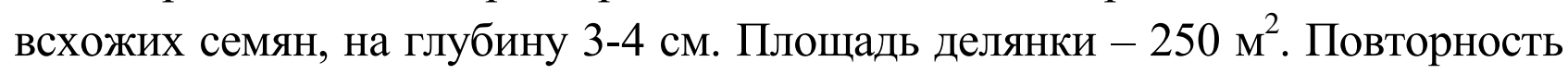
опыта 3-кратная, расположение систематическое. Предшественник - соя. 
Схема опыта по изучению влияния плодородия почвы на урожайность яровой пшеницы включала 9 вариантов:

1. Контроль (без удобрений);

2. $\mathrm{H}_{260}+И_{9}$ (последействие удобрений);

3. $\mathrm{H}_{260}+\mathrm{И}_{9}+\mathrm{N}_{2750} \mathrm{P}_{2760} \mathrm{~K}_{1635}$ (последействие удобрений);

4. $\mathrm{H}_{420}+\mathrm{И}_{9}+\mathrm{N}_{2138} \mathrm{P}_{4110} \mathrm{~K}_{1570}$ (последействие удобрений);

5. Контроль (без удобрений);

6. $\mathrm{H}_{220}+\mathrm{U}_{22}+\mathrm{N}_{1033} \mathrm{P}_{1410} \mathrm{~K}_{1125}+$ под пшеницу $\mathrm{N}_{30} \mathrm{P}_{45} \mathrm{~K}_{45}$ (действие удобрений);

7. $\mathrm{H}_{220}+\mathrm{U}_{22}+\mathrm{N}_{1033} \mathrm{P}_{1410} \mathrm{~K}_{1125}+$ под пшеницу $\mathrm{N}_{60} \mathrm{P}_{90} \mathrm{~K}_{90}$ (действие удобрений);

8. $И_{30}+\mathrm{N}_{1055} \mathrm{P}_{1270} \mathrm{~K}_{985}+$ под пшеницу $\mathrm{N}_{30} \mathrm{P}_{45} \mathrm{~K}_{45}$ (действие удобрений);

9. $\mathrm{N}_{2620} \mathrm{P}_{2855} \mathrm{~K}_{2100}+$ под пшеницу $\mathrm{N}_{60} \mathrm{P}_{90} \mathrm{~K}_{90}$ (действие удобрений).

Системы удобрений включали раздельное внесение навоза, извести и минеральных удобрений (в одинарных и двойных дозах в виде диаммофоски $\mathrm{N}_{10} \mathrm{P}_{26} \mathrm{~K}_{26}$ и аммиачной селитры), а также в их различных сочетаниях. Навоз и известь вносили в начале каждой ротации севооборота, минеральные удобрения - ежегодно. Уборку проводили в фазу полной спелости зерна комбайном Sampo 130. Статистическую обработку экспериментальных данных проводили по методике Б.А. Доспехова [Доспехов, 2014].

Результаты и обсуждение

Яровая пшеница очень отзывчива на внесение удобрений, больше всего она извлекает из почвы азота, меньше калия и еще меньше фосфора [Федоров, 1998]. Недостаток в азоте она испытывает в одну из важных фаз развития - налив зерна. С увеличением обеспеченности растений азотом улучшается вегетативная масса, возрастает белковость зерна. Наибольшая потребность в фосфоре наблюдается в период от начала кущения до выхода в трубку. Фосфорное питание оказывает большое влияние на развитие корневой системы и колосков и меньше - на развитие стеблей и листьев. Калий оказывает значительное влияние во время колошения и налива зерна. Он ускоряет передвижение углеводов из стеблей и листьев в зерно, снижает поражение ржавчиной, что способствует формированию крупного и выполненного зерна. Максимальную эффективность оказывает полное минеральное удобрение при сочетании органических удобрений и известкования [Грицун, 1964; Грицун, 1971].

В результате проведенных исследований установлено, что содержание общего азота, фосфора и калия в надземной массе растений пшеницы было наибольшим в вариантах по действию удобрений, а минимальные 
значения содержания NPK выявлены по последействию различных систем удобрений (табл. 2).

Количество общего азота в наземной массе растений в фазу кущения на контроле соответствовало низкому содержанию данного элемента в этот период и по действию и по последействию. При применении $\mathrm{H}_{260}+\mathrm{И}_{9}$ и $\mathrm{H}_{420}+\mathrm{h}_{9}+\mathrm{N}_{2138} \mathrm{P}_{4110} \mathrm{~K}_{1570}$ содержание азота увеличивалось в 1,4 раза по последействию, а при действии удобрений на всех вариантах опыта в 1-1,4 раза. Содержание азота в фазу колошения в контрольных растениях было низким. В вариантах с использованием $\mathrm{H}_{260}+\mathrm{h}_{9}$ и $\mathrm{H}_{260}+\mathrm{h}_{9}+\mathrm{N}_{2750} \mathrm{P}_{2760} \mathrm{~K}_{1635}$ количество азота в надземной массе достигало 1,21 и 1,49 \% соответственно по последействию, и 1,47-1,67 \% на всех вариантах по действию удобрений.

Обеспеченность фосфором растений в контрольном варианте в фазу кущения была наименьшей по последействию. Содержание данного элемента в надземной массе растений по действующим системам удобрений составило 0,21\% и 0,29 \%. В фазу колошения, согласно полученным результатам, растения на контроле испытывали некоторый недостаток этого элемента питания. При применении разных фонов удобрений содержание общего фосфора в фазу кущения увеличивалось по всем вариантам последействия, и на фоне $\mathrm{H}_{220}+\mathrm{U}_{22}+\mathrm{N}_{1033} \mathrm{P}_{1410} \mathrm{~K}_{1125}+$ под пшеницу $\mathrm{N}_{30} \mathrm{P}_{45} \mathrm{~K}_{45}$ и $\mathrm{H}_{220}+\mathrm{U}_{22}+\mathrm{N}_{2633} \mathrm{P}_{2780} \mathrm{~K}_{2153}+$ под пшеницу $\mathrm{N}_{60} \mathrm{P}_{90} \mathrm{~K}_{90}$. В фазу колошения значения изучаемого показателя незначительно превышали контроль на всех вариантах по действию, а на фоне $\mathrm{H}_{260}+\mathrm{h}_{9}$ и $\mathrm{H}_{260}+\mathrm{U}_{9}+\mathrm{N}_{2750} \mathrm{P}_{2760} \mathrm{~K}_{1635}$ по последействию удобрений. В течение вегетационного периода содержание общего калия в надземной массе растений пшеницы, значительно отличалось. При применении $\mathrm{H}_{220}+\mathrm{h}_{22}+\mathrm{N}_{1033} \mathrm{P}_{1410} \mathrm{~K}_{1125}+$ Под пшеницу $\mathrm{N}_{60} \mathrm{P}_{90} \mathrm{~K}_{90}$ (действие удобрений) содержание калия в растениях увеличивалось в $1,1-1,2$ раз в зависимости от фазы вегетации. Наиболее высокие показатели в течение всего вегетационного периода (в разные фазы развития) отмечены в вариантах $\mathrm{H}_{220}+\mathrm{U}_{22}+\mathrm{N}_{1033} \mathrm{P}_{1410} \mathrm{~K}_{1125}+$ под пшеницу $\mathrm{N}_{60} \mathrm{P}_{90} \mathrm{~K}_{90}$, $\mathrm{U}_{30}+\mathrm{N}_{1055} \mathrm{P}_{1270} \mathrm{~K}_{985}+$ под пшеницу $\mathrm{N}_{30} \mathrm{P}_{45} \mathrm{~K}_{45}$ и $\mathrm{N}_{2620} \mathrm{P}_{2855} \mathrm{~K}_{2100}+$ под пшеницу $\mathrm{N}_{60} \mathrm{P}_{90} \mathrm{~K}_{90}$ по действию удобрений и на фоне $\mathrm{H}_{260}+\mathrm{U}_{9}+\mathrm{N}_{2750} \mathrm{P}_{2760} \mathrm{~K}_{1635}$ в фазу кущения, $\mathrm{H}_{420}+\mathrm{h}_{9}+\mathrm{N}_{2138} \mathrm{P}_{4110} \mathrm{~K}_{1570}$ в период восковой спелости зерна по последействию удобрений.

В зависимости от условий минерального питания химический состав и качество зерна подвергаются значительным изменениям. Изучением действия удобрений на качество зерна злаков в нашей стране впервые бы- 
ло начато в лаборатории Д.Н. Прянишникова. Исследования показали, что наибольшее положительное действие на накопление белка в зерне оказывают азотные удобрения. Накопление белка происходит в результате реутилизации азотистых веществ, содержащихся в вегетативных органах до начала налива зерен и поглощения азота из почвы [Ягодин, 2002]. Усиление фосфорного питания растений вызывает сниженное содержание белка в зерне. Фосфор усиливает рост растений, повышает урожай зерна и вегетативной массы, что приводит к «разбавлению» азота в растении, растение испытывает недостаток азота, и зерно формируется с более низким содержанием белка.

Таблийа 2

Динамика содержания азота, фосфора и калия

в растениях яровой пшеницы под влиянием разных систем удобрений, \% на абсолютно сухое вещество

\begin{tabular}{|c|c|c|c|c|c|c|c|c|c|}
\hline \multirow{3}{*}{ Вариант } & \multicolumn{9}{|c|}{ Фаза развития } \\
\hline & \multicolumn{3}{|c|}{ кущение } & \multicolumn{3}{|c|}{ колошение } & \multicolumn{3}{|c|}{$\begin{array}{l}\text { восковая } \\
\text { спелость }\end{array}$} \\
\hline & $\mathrm{N}$ & $\mathrm{P}$ & K & $\mathrm{N}$ & $\mathrm{P}$ & K & $\mathrm{N}$ & $\mathrm{P}$ & $\mathrm{K}$ \\
\hline \multicolumn{10}{|c|}{ Последействие удобрений } \\
\hline $\begin{array}{c}\text { Контроль } \\
\text { (без удобрений) }\end{array}$ & 1,95 & 0,21 & 3,52 & 1,09 & 0,16 & 1,33 & 1,44 & 0,17 & 0,80 \\
\hline $\mathrm{H}_{260}+\mathrm{U}_{9}$ & 2,46 & 0,27 & 3,36 & 1,21 & 0,17 & 1,21 & 0,94 & 0,16 & 0,86 \\
\hline $\mathrm{H}_{260}+\mathrm{U}_{9}+\mathrm{N}_{2750} \mathrm{P}_{2760} \mathrm{~K}_{1635}$ & 1,69 & 0,30 & 3,88 & 1,49 & 0,19 & 1,13 & 1,25 & 0,16 & 0,86 \\
\hline $\mathrm{H}_{420}+\mathrm{U}_{9}+\mathrm{N}_{2138} \mathrm{P}_{4110} \mathrm{~K}_{1570}$ & 2,68 & 0,40 & 3,13 & 1,06 & 0,15 & 1,22 & 1,12 & 0,15 & 0,96 \\
\hline $\mathrm{HCP}_{0,95}$ & 0,13 & 0,06 & 0,39 & 0,19 & 0,03 & 0,03 & 0,14 & 0,03 & 0,02 \\
\hline \multicolumn{10}{|c|}{ Действие удобрений } \\
\hline $\begin{array}{c}\text { Контроль } \\
\text { (без удобрений) }\end{array}$ & 2,38 & 0,29 & 3,80 & 1,27 & 0,17 & 1,27 & 1,24 & 0,16 & 0,95 \\
\hline $\begin{array}{c}\mathrm{H}_{220}+\mathrm{U}_{22}+\mathrm{N}_{1033} \mathrm{P}_{1410} \mathrm{~K}_{1125} \\
+ \text { под пшеницу } \mathrm{N}_{30} \mathrm{P}_{45} \mathrm{~K}_{45}\end{array}$ & 3,26 & 0,33 & 3,87 & 1,56 & 0,20 & 1,40 & 1,20 & 0,15 & 0,90 \\
\hline $\begin{array}{r}\mathrm{H}_{220}+\mathrm{U}_{22}+\mathrm{N}_{2633} \mathrm{P}_{2780} \mathrm{~K}_{2153} \\
+ \text { под пшеницу } \mathrm{N}_{60} \mathrm{P}_{90} \mathrm{~K}_{90}\end{array}$ & 3,21 & 0,36 & 4,65 & 1,47 & 0,21 & 1,32 & 1,25 & 0,18 & 1,07 \\
\hline $\begin{array}{c}\mathrm{U}_{30}+\mathrm{N}_{1055} \mathrm{P}_{1270} \mathrm{~K}_{985} \\
+ \text { под пшеницу } \mathrm{N}_{30} \mathrm{P}_{45} \mathrm{~K}_{45}\end{array}$ & 3,00 & 0,29 & 3,85 & 1,60 & 0,22 & 1,60 & 1,24 & 0,17 & 1,27 \\
\hline $\begin{array}{c}\mathrm{N}_{2620} \mathrm{P}_{2855} \mathrm{~K}_{2100} \\
\text { +под пшеницу } \mathrm{N}_{60} \mathrm{P}_{90} \mathrm{~K}_{90}\end{array}$ & 2,54 & 0,28 & 3,48 & 1,67 & 0,20 & 1,38 & 1,37 & 0,17 & 0,98 \\
\hline $\mathrm{HCP}_{0,95}$ & 0,15 & 0,04 & 0,34 & 0,05 & 0,08 & 0,13 & 0,14 & 0,04 & 0,03 \\
\hline
\end{tabular}


Фосфорные и калийные удобрения, внесенные без азотных, слабо влияют на накопления белка, а наибольшее положительное действие на повышение содержания белка наблюдается при совместном внесении азотных, фосфорных и калийных удобрений и правильном их сочетании, с учетом свойств почвы и потребностей растений. При оптимальном снабжении растений всеми питательными элементами содержание белка в зерне повышается [Агрохимия, 1975.]. На почвах с очень низким содержанием подвижного фосфора удобрения не снижали или даже несколько повышали содержание белка в зерне пшеницы. Калийные удобрения, вносимые в обычных нормах, не изменяют или даже несколько повышают содержание белка в зерне. Однако повышенные нормы калийных удобрений могут значительно снижать содержание белка в зерне. Отрицательное действие высоких норм калийных удобрений на содержание белка в зерне объясняется тем, что в зерновых культурах существует обратная зависимость между содержанием белков и крахмала. Чем больше крахмала накапливается в зерне, тем меньше в нем содержится белков. Калий необходим в значительных количествах для нормального роста и развития и для биосинтеза белков, но он более интенсивно стимулирует синтез и передвижение углеводов, чем синтез азотистых веществ. Поэтому при внесении повышенных норм калийных удобрений в сильной степени повышается синтез углеводов, их передвижение в созревающие семена, в них накапливается много крахмала, а относительное содержание белков соответственно снижается [Ягодин, 2002].

Систематическое применение органических и минеральных удобрений на фоне известкования в севообороте оказало неодинаковое влияние на накопление азота, фосфора и калия в зерне яровой пшеницы (табл. 3). На фоне последействия удобрений максимальное содержание общего азота и фосфора отмечено на контрольном варианте, а калия на фоне $\mathrm{H}_{260}+И_{9}$. При действии удобрений содержание общего азота варьировало (2,70-2,85 \%) и было наиболее высоким (2,85 \%) при применении $\mathrm{H}_{220}+\mathrm{U}_{22}+\mathrm{N}_{1033} \mathrm{P}_{1410} \mathrm{~K}_{1125}+$ под пшеницу $\mathrm{N}_{30} \mathrm{P}_{45} \mathrm{~K}_{45}$, а самым низким при $\mathrm{H}_{220}+\mathrm{U}_{22}+\mathrm{N}_{2633} \mathrm{P}_{2780} \mathrm{~K}_{2153}+$ под пшеницу $\mathrm{N}_{60} \mathrm{P}_{90} \mathrm{~K}_{90}$. Содержание фосфора в зерне было максимальным в варианте $\mathrm{H}_{220}+\mathrm{U}_{22}+\mathrm{N}_{2633} \mathrm{P}_{2780} \mathrm{~K}_{2153}+$ под пшеницу $\mathrm{N}_{60} \mathrm{P}_{90} \mathrm{~K}_{90}(0,55 \%) \quad$ и $\mathrm{H}_{220}+\mathrm{U}_{22}+\mathrm{N}_{2633} \mathrm{P}_{2780} \mathrm{~K}_{2153}+$ под пшеницу $\mathrm{N}_{60} \mathrm{P}_{90} \mathrm{~K}_{90}$ содержание калия находилось на уровне контроля (0,44\%), а остальные варианты опыта не превысили его. 
Влияние разных систем удобрений на содержание азота, фосфора и калия в зерне, \%

\begin{tabular}{|c|c|c|c|}
\hline Вариант & Азот & Фосфор & Калий \\
\hline \multicolumn{4}{|c|}{ Последействие удобрений } \\
\hline $\begin{array}{c}\text { Контроль } \\
\text { (без удобрений) }\end{array}$ & 2,67 & 0,56 & 0,43 \\
\hline $\mathrm{H}_{260}+\mathrm{U}_{9}$ & 2,39 & 0,51 & 0,53 \\
\hline $\mathrm{H}_{260}+\mathrm{U}_{9}+\mathrm{N}_{2750} \mathrm{P}_{2760} \mathrm{~K}_{1635}$ & 2,46 & 0,42 & 0,46 \\
\hline $\mathrm{H}_{420}+\mathrm{U}_{9}+\mathrm{N}_{2138} \mathrm{P}_{4110} \mathrm{~K}_{1570}$ & 2,59 & 0,52 & 0,43 \\
\hline $\mathrm{HCP}_{0,95}$ & & & \\
\hline \multicolumn{4}{|c|}{ Действие удобрений } \\
\hline $\begin{array}{c}\text { Контроль } \\
\text { (без удобрений) }\end{array}$ & 2,79 & 0,52 & 0,44 \\
\hline $\begin{array}{l}\mathrm{H}_{220}+\mathrm{U}_{22}+\mathrm{N}_{1033} \mathrm{P}_{1410} \mathrm{~K}_{1125} \\
+ \text { под пшеницу } \mathrm{N}_{30} \mathrm{P}_{45} \mathrm{~K}_{45}\end{array}$ & 2,88 & 0,53 & 0,41 \\
\hline $\begin{array}{l}\mathrm{H}_{220}+\mathrm{U}_{22}+\mathrm{N}_{2633} \mathrm{P}_{2780} \mathrm{~K}_{2153} \\
+ \text { под пшеницу } \mathrm{N}_{60} \mathrm{P}_{90} \mathrm{~K}_{90}\end{array}$ & 2,70 & 0,55 & 0,44 \\
\hline $\begin{array}{c}\mathrm{U}_{30}+\mathrm{N}_{1055} \mathrm{P}_{1270} \mathrm{~K}_{985} \\
+ \text { под пшеницу } \mathrm{N}_{30} \mathrm{P}_{45} \mathrm{~K}_{45}\end{array}$ & 2,85 & 0,52 & 0,39 \\
\hline $\begin{array}{c}\mathrm{N}_{2620} \mathrm{P}_{2855} \mathrm{~K}_{2100} \\
\text { +под пшеницу } \mathrm{N}_{60} \mathrm{P}_{90} \mathrm{~K}_{90}\end{array}$ & 2,73 & 0,54 & 0,39 \\
\hline $\mathrm{HCP}_{0,95}$ & 0,21 & 0,04 & 0,03 \\
\hline
\end{tabular}

Использование органических и минеральных удобрений на фоне известкования повышает плодородие почвы, создавая оптимальные условия для возделывания сельскохозяйственных культур [Рабинович, 2015]. Именно удобрения являются важнейшим фактором интенсификации земледелия [Романенко, 1998; Soon, 1988; Mudahar, 1980; Niehoff, 1981]. Большое значение имеет известкование. Раскисление почвы способствует мобилизации запасов питательных элементов и повышению эффективности минеральных удобрений. Внесение извести на кислых лугово-бурых почвах - эффективный прием повышения их плодородия. Использование минеральных удобрений без извести приводит к снижению урожая.

Для воспроизводства плодородия лугово-бурых почв и повышения урожайности сельскохозяйственных культур, необходимо периодическое внесение в севообороте органических удобрений, извести и ежегодное минеральных удобрений в умеренных дозах [Моисеенко, 2005]. Длитель- 
ное применение разных систем удобрений оказывает существенное влияние на накопление элементов питания в почве и изменение агрохимических показателей и плодородие почвы [Тимошинов, 2018]. В результате длительного применения удобрений в вариантах опыта сформировались определенные уровни плодородия почвы (табл. 4). Установлено что, повышение почвенного плодородия увеличивает урожайность сельскохозяйственных культур. На фоне последействия при совместном применении органических и минеральных удобрений с известкованием, плодородие почв оценивалось как «хорошее», и урожайность увеличилась в 1,3 раза в сравнении с контролем. В действии влияние систем удобрений на урожайность яровой пшеницы оказало в варианте с внесением $\mathrm{H}_{220}+\mathrm{K}_{22}+\mathrm{N}_{1033} \mathrm{P}_{1410} \mathrm{~K}_{1125}+$ под пшеницу $\mathrm{N}_{60} \mathrm{P}_{90} \mathrm{~K}_{90}$, где урожайность составила 3,9 т/га. На контроле, где удобрения не вносили, урожайность - 2,61 т/га.

Изучение качества зерна яровой пшеницы показало что, на фоне последействия систем удобрений высокое содержание крахмала выше контроля на всех вариантах опыта. Максимальное значение этого показателя зафиксировано в варианте $\mathrm{H}_{260}+И_{9}$ при низком плодородии почвы и урожайности 2,71 т/га. При действующей системе удобрений увеличивались показатели качества зерна, как белок и крахмал на вариантах $\mathrm{H}_{220}+И_{22}+\mathrm{N}_{1033} \mathrm{P}_{1410} \mathrm{~K}_{1125}+$ под пшеницу $\mathrm{N}_{30} \mathrm{P}_{45} \mathrm{~K}_{45}$ и $И_{30}+\mathrm{N}_{1055} \mathrm{P}_{1270} \mathrm{~K}_{985}+$ под пшеницу $\mathrm{N}_{30} \mathrm{P}_{45} \mathrm{~K}_{45}$ и составили 16,42, 16,23 \% и 57,51, 57,60 \% соответственно, относительно контроля (белок - 15,90\%, крахмал $-56,48 \%$ ).

Минеральные и органические удобрения при длительном применении в севообороте оказывают не только прямое действие, но и продолжительное последействие на урожайность яровой пшеницы [Моисеенко, 2006; Моисеенко, 2007; Хасбиулина, 2009; Бережная, 2018]. В результате проведенных исследований установлено, что хорошее плодородие почвы обеспечивает рост урожайности и повышение качества зерна. Наибольший урожай отмечен при сочетании органических, двойных доз минеральных удобрений и известкования на фоне действия удобрений.

Основными элементами структуры урожая яровой пшеницы являются количество продуктивных стеблей и элементы колоса (длина колоса, количество зерен в колосе). В фазу полной спелости зерна исследованы следующие элементы структуры урожая: количество растений, число зерен в колосе, масса - 1000 зерен (табл.5). Количество продуктивных растений варьировало по вариантам опыта на фоне последействия и действия удобрений от 229-407 
шт./м² и 220-325 шт./м² соответственно. Наибольшее число растений яровой пшеницы - 407 шт./ $\mathrm{M}^{2}$ отмечено по последействию $\mathrm{H}_{260}+\mathrm{U}_{9}+\mathrm{N}_{2750} \mathrm{P}_{2760} \mathrm{~K}_{1635}$ при удовлетворительном плодородии почвы, где структурные показатели, такие как высота растения (107 см), количество зерен в колосе (27 шт.) и масса 1000 зерен $(34,8$ г) были максимальны, что в свою очередь, способствовало формированию урожайности - 2,94 т/га. Минимальное количество растений -229 шт./м² и урожайностью 2,40 т/га отмечено на контроле при этом структурные показатели не значительно отличались от остальных вариантов опыта.

Таблица 4

\section{Влияние плодородия почвы на урожайность}

и качество зерна яровой пшеницы

\begin{tabular}{|c|c|c|c|c|c|}
\hline \multirow[t]{2}{*}{ Вариант } & \multirow[t]{2}{*}{ КАП } & \multirow{2}{*}{$\begin{array}{c}\text { Оценка } \\
\text { плодородия } \\
\text { почвы }\end{array}$} & \multicolumn{2}{|c|}{$\begin{array}{c}\text { Содержание в зерне, } \\
\text { \% на абс. сух. веще- } \\
\text { ство }\end{array}$} & \multirow{2}{*}{$\begin{array}{l}\text { Урожай- } \\
\text { ность, т/га }\end{array}$} \\
\hline & & & белка & крахмала & \\
\hline \multicolumn{6}{|c|}{ Последействие удобрений } \\
\hline $\begin{array}{c}\text { Контроль } \\
\text { (без удобрений) }\end{array}$ & - & - & 15,23 & 58,13 & 2,40 \\
\hline $\mathrm{H}_{260}+\mathrm{U}_{9}$ & 40,60 & низкое & 13,60 & 60,44 & 2,71 \\
\hline $\mathrm{H}_{260}+\mathrm{U}_{9}+\mathrm{N}_{2750} \mathrm{P}_{2760} \mathrm{~K}_{1635}$ & 54,40 & $\begin{array}{l}\text { удовлетво- } \\
\text { рительное }\end{array}$ & 14,05 & 58,42 & 2,94 \\
\hline $\mathrm{H}_{420}+\mathrm{U}_{9}+\mathrm{N}_{2138} \mathrm{P}_{4110} \mathrm{~K}_{1570}$ & 61,80 & хорошее & 14,77 & 59,04 & 3,15 \\
\hline $\mathrm{HCP}_{0,95}$ & - & - & - & - & 0,25 \\
\hline \multicolumn{6}{|c|}{ Действие удобрений } \\
\hline $\begin{array}{c}\text { Контроль } \\
\text { (без удобрений) }\end{array}$ & & - & 15,90 & 56,48 & 2,61 \\
\hline $\begin{array}{l}\mathrm{H}_{220}+\mathrm{U}_{22}+\mathrm{N}_{1033} \mathrm{P}_{1410} \mathrm{~K}_{1125} \\
+ \text { под пшеницу } \mathrm{N}_{30} \mathrm{P}_{45} \mathrm{~K}_{45}\end{array}$ & 51,35 & $\begin{array}{l}\text { удовлетво- } \\
\text { рительное }\end{array}$ & 16,42 & 57,51 & 3,67 \\
\hline $\begin{array}{l}\mathrm{H}_{220}+\mathrm{U}_{22}+\mathrm{N}_{2633} \mathrm{P}_{2780} \mathrm{~K}_{2153} \\
+ \text { +под пшенишv } \mathrm{N}_{60} \mathrm{P}_{00} \mathrm{~K}_{00}\end{array}$ & 65,30 & хорошее & 15,40 & 56,99 & 3,90 \\
\hline $\begin{array}{c}\mathrm{U}_{30}+\mathrm{N}_{1055} \mathrm{P}_{1270} \mathrm{~K}_{985} \\
+ \text { +под пшеницу } \mathrm{N}_{30} \mathrm{P}_{45} \mathrm{~K}_{45}\end{array}$ & 52,10 & $\begin{array}{l}\text { удовлетво- } \\
\text { рительное }\end{array}$ & 16,23 & 57,60 & 3,60 \\
\hline $\begin{array}{c}\mathrm{N}_{2620} \mathrm{P}_{2855} \mathrm{~K}_{2100} \\
+ \text { +под пшеницу } \mathrm{N}_{60} \mathrm{P}_{90} \mathrm{~K}_{90}\end{array}$ & 38,70 & низкое & 15,56 & 56,22 & 3,58 \\
\hline $\mathrm{HCP}_{0,95}$ & - & - & - & - & 0,32 \\
\hline
\end{tabular}

При действующей системе удобрений наименьшее количество растений- 220 шт./м ${ }^{2}$ выявлено в варианте $\mathrm{H}_{220}+\mathrm{h}_{22}+\mathrm{N}_{1033} \mathrm{P}_{1410} \mathrm{~K}_{1125}+$ под пше- 
ницу $\mathrm{N}_{30} \mathrm{P}_{45} \mathrm{~K}_{45}$ с высокими структурными показателями длиной колоса (9 см) и массой 1000 зерен $(35,0$ г). При длительном применении $\mathrm{H}_{220}+\mathrm{U}_{22}+\mathrm{N}_{2633} \mathrm{P}_{2780} \mathrm{~K}_{2153}+$ под пшеницу $\mathrm{N}_{60} \mathrm{P}_{90} \mathrm{~K}_{90}$ с хорошим плодородием отмечено наибольшее количество растений 325 шт./м², высота растений 115 см и урожайность - 3,90 т/га. В контроле количество растений составило 292 шт./м², при высоте растений 102 см, что способствовало формированию урожайности 2,61 т/га с наименьшей массой 1000 зерен - 31,3 г.

Таблица 5

\section{Изменение продуктивности растений яровой пшеницы}

в зависимости от действия и последействия удобрений

\begin{tabular}{|c|c|c|c|c|c|}
\hline Вариант & $\begin{array}{c}\text { Количе- } \\
\text { ство рас- } \\
\text { тений, } \\
\text { шт./м² }\end{array}$ & $\begin{array}{c}\text { Высота } \\
\text { растения, } \\
\text { см }\end{array}$ & $\begin{array}{c}\text { Длина } \\
\text { колоса, } \\
\text { см }\end{array}$ & $\begin{array}{c}\text { Количе- } \\
\text { ство } \\
\text { зерен в } \\
\text { колосе, } \\
\text { шт. }\end{array}$ & $\begin{array}{c}\text { Macca } \\
1000 \\
\text { зерен, г }\end{array}$ \\
\hline \multicolumn{6}{|c|}{ Последействие удобрений } \\
\hline $\begin{array}{c}\text { Контроль } \\
\text { (без удобрений) }\end{array}$ & 229 & 100 & 8 & 25 & 34,1 \\
\hline $\mathrm{H}_{260}+\mathrm{U}_{9}$ & 240 & 105 & 8 & 25 & 33,5 \\
\hline $\mathrm{H}_{260}+\mathrm{U}_{9}+\mathrm{N}_{2750} \mathrm{P}_{2760} \mathrm{~K}_{1635}$ & 407 & 107 & 8 & 27 & 34,8 \\
\hline $\mathrm{H}_{420}+\mathrm{U}_{9}+\mathrm{N}_{2138} \mathrm{P}_{4110} \mathrm{~K}_{1570}$ & 393 & 105 & 7 & 23 & 34,1 \\
\hline $\mathrm{HCP}_{0,95}$ & 15,0 & 9,5 & 0,4 & 1,5 & 2,4 \\
\hline \multicolumn{6}{|c|}{ Действие удобрений } \\
\hline $\begin{array}{c}\text { Контроль } \\
\text { (без удобрений) }\end{array}$ & 292 & 102 & 8 & 32 & 31,3 \\
\hline $\begin{array}{l}\mathrm{H}_{220}+\mathrm{U}_{22}+\mathrm{N}_{1033} \mathrm{P}_{1410} \mathrm{~K}_{1125} \\
+ \text { под пшеницу } \mathrm{N}_{30} \mathrm{P}_{45} \mathrm{~K}_{45}\end{array}$ & 220 & 111 & 9 & 28 & 35,0 \\
\hline $\begin{array}{c}\mathrm{H}_{220}+\mathrm{U}_{22}+\mathrm{N}_{2633} \mathrm{P}_{2780} \mathrm{~K}_{2153} \\
+ \text { под пшеницу } \mathrm{N}_{60} \mathrm{P}_{90} \mathrm{~K}_{90}\end{array}$ & 325 & 115 & 8 & 30 & 34,3 \\
\hline $\begin{array}{c}\mathrm{U}_{30}+\mathrm{N}_{1055} \mathrm{P}_{1270} \mathrm{~K}_{985} \\
+ \text { под пшеницу } \mathrm{N}_{30} \mathrm{P}_{45} \mathrm{~K}_{45}\end{array}$ & 263 & 110 & 8 & 26 & 34,1 \\
\hline $\begin{array}{c}\mathrm{N}_{2620} \mathrm{P}_{2855} \mathrm{~K}_{2100} \\
\text { +под пшеницу } \mathrm{N}_{60} \mathrm{P}_{90} \mathrm{~K}_{90}\end{array}$ & 312 & 110 & 9 & 30 & 33,1 \\
\hline $\mathrm{HCP}_{0,95}$ & 17,0 & 10,1 & 0,4 & 2,0 & 2,5 \\
\hline
\end{tabular}

Для получения высококачественных урожаев с помощью удобрений необходимо учитывать роль отдельных элементов питания в жизни растений. Биологические особенности растений, основные закономерности 
процессов обмена веществ, свойства удобрений, свойства почвы и другие условия [Ягодин, 2002]. Таким образом, применение разных систем по последействию и действию удобрений оказывает влияние на плодородие почвы, что способствует росту и развитию растений яровой пшеницы и формирование структуры урожая и его качества.

Наиболее высокое содержание основных элементов питания в растениях пшеницы при применении $\mathrm{H}_{220}+\mathrm{U}_{22}+\mathrm{N}_{2633} \mathrm{P}_{2780} \mathrm{~K}_{2153}+$ под пшеницу $\mathrm{N}_{60} \mathrm{P}_{90} \mathrm{~K}_{90}$ по действию удобрений отмечено в течение всего вегетационного периода. В фазу кущения содержание общего азота в изучаемых вариантах варьировало от 2,46 до 2,68 \% по последействию и 2,54-3,26 \% по действию удобрений. Высокий уровень 3,26 \% выявлен в варианте $\mathrm{H}_{220}+\mathrm{h}_{22}+\mathrm{N}_{1033} \mathrm{P}_{1410} \mathrm{~K}_{1125}+$ под пшеницу $\mathrm{N}_{60} \mathrm{P}_{90} \mathrm{~K}_{90}$. В период колошения при применении $\mathrm{N}_{2620} \mathrm{P}_{2855} \mathrm{~K}_{2100}+$ под пшеницу $\mathrm{N}_{60} \mathrm{P}_{90} \mathrm{~K}_{90}$, он составил $1,67 \%$, а в фазу восковой спелости с использованием $\mathrm{H}_{220}+\mathrm{U}_{22}+\mathrm{N}_{1033} \mathrm{P}_{1410} \mathrm{~K}_{1125}+$ под пшеницу $\mathrm{N}_{60} \mathrm{P}_{90} \mathrm{~K}_{90}-0,18 \%$.

Количество фосфора в надземной массе растений пшеницы было различным и по последействию и по действию удобрений. Максимальные значения отмечены в вариантах $\mathrm{H}_{220}+\mathrm{U}_{22}+\mathrm{N}_{1033} \mathrm{P}_{1410} \mathrm{~K}_{1125}+$ под пшеницу $\mathrm{N}_{30} \mathrm{P}_{45} \mathrm{~K}_{45}$ и $\mathrm{H}_{220}+\mathrm{U}_{22}+\mathrm{N}_{1033} \mathrm{P}_{1410} \mathrm{~K}_{1125}+$ под пшеницу $\mathrm{N}_{60} \mathrm{P}_{90} \mathrm{~K}_{90}$ (действие удобрений), где содержание фосфора возрастало в 1,1 и 1,2 раза соответственно относительно контроля.

В варианте $\mathrm{H}_{220}+\mathrm{U}_{22}+\mathrm{N}_{1033} \mathrm{P}_{1410} \mathrm{~K}_{1125}+$ под пшеницу $\mathrm{N}_{60} \mathrm{P}_{90} \mathrm{~K}_{90}$ (действие удобрений) содержание калия в растениях увеличивалось в 1,1-1,2 раз в разные фазы вегетации. Наиболее высокие показатели в течение всего вегетационного периода в разные фазы вегетации отмечены в вариантах $\mathrm{H}_{220}+\mathrm{U}_{22}+\mathrm{N}_{1033} \mathrm{P}_{1410} \mathrm{~K}_{1125}+$ под пшеницу $\mathrm{N}_{60} \mathrm{P}_{90} \mathrm{~K}_{90}, \quad \mathrm{И}_{30}+\mathrm{N}_{1055} \mathrm{P}_{1270} \mathrm{~K}_{985}+$ под пшеницу $\mathrm{N}_{30} \mathrm{P}_{45} \mathrm{~K}_{45}$ и $\mathrm{N}_{2620} \mathrm{P}_{2855} \mathrm{~K}_{2100}+$ под пшеницу $\mathrm{N}_{60} \mathrm{P}_{90} \mathrm{~K}_{90}$ по действию удобрений и на фоне $\mathrm{H}_{260}+\mathrm{h}_{9}+\mathrm{N}_{2750} \mathrm{P}_{2760} \mathrm{~K}_{1635}$ в фазу кущения, $\mathrm{H}_{420}+\mathrm{U}_{9}+\mathrm{N}_{2138} \mathrm{P}_{4110} \mathrm{~K}_{1570}$ в период восковой спелости зерна по последействию удобрений.

Применение разных фонов в севообороте оказало неоднозначное влияние на накопление азота, фосфора и калия в зерне яровой пшеницы. На фоне последействия удобрений максимальное содержание общего азота и фосфора отмечено на контрольном варианте, а калия на фоне $\mathrm{H}_{260}+\mathrm{h}_{9}$. При действии удобрений содержание общего азота варьировало от 2,70- 
$2,85 \%$ и было наиболее высоким (2,85 \%) при применении $\mathrm{H}_{220}+\mathrm{h}_{22}+\mathrm{N}_{1033} \mathrm{P}_{1410} \mathrm{~K}_{1125}+$ под пшеницу $\mathrm{N}_{30} \mathrm{P}_{45} \mathrm{~K}_{45}$.

На фоне последействия систем удобрений установлено высокое содержание крахмала на всех вариантах опыта. При действующей системе удобрений увеличивались показатели качества зерна, как белок и крахмал на вариантах $\mathrm{H}_{220}+\mathrm{И}_{22}+\mathrm{N}_{1033} \mathrm{P}_{1410} \mathrm{~K}_{1125}+$ под пшеницу $\mathrm{N}_{30} \mathrm{P}_{45} \mathrm{~K}_{45}$ и $И_{30}+\mathrm{N}_{1055} \mathrm{P}_{1270} \mathrm{~K}_{985}+$ под пшеницу $\mathrm{N}_{30} \mathrm{P}_{45} \mathrm{~K}_{45}$ и составили $16,42,16,23 \%$ и 57,51, 57,60 \% соответственно, относительно контроля (белок - 15,90\%, крахмал - 56,48\%).

Количество продуктивных растений варьировало по вариантам опыта на фоне последействия и действия удобрений от 229-407 шт./м² и 220325 шт./м² соответственно. Наибольшее число растений яровой пшеницы 407 шт./м² отмечено по последействию $\mathrm{H}_{260}+\mathrm{h}_{9}+\mathrm{N}_{2750} \mathrm{P}_{2760} \mathrm{~K}_{1635}$. При действующей системе удобрений наименьшее количество растений- 220 шт./м² было в варианте $\mathrm{H}_{220}+\mathrm{h}_{22}+\mathrm{N}_{1033} \mathrm{P}_{1410} \mathrm{~K}_{1125}+$ под пшеницу $\mathrm{N}_{30} \mathrm{P}_{45} \mathrm{~K}_{45}$.

Установлено что, повышение почвенного плодородия увеличивает урожайность сельскохозяйственных культур, на фоне последействия урожайность увеличилась в 1,3 раза в сравнении с контролем. Минимальное влияние систем удобрений на урожайность (3,9 т/га) яровой пшеницы выявлено в варианте с внесением $\mathrm{H}_{220}+\mathrm{h}_{22}+\mathrm{N}_{1033} \mathrm{P}_{1410} \mathrm{~K}_{1125}+$ под пшеницу $\mathrm{N}_{60} \mathrm{P}_{90} \mathrm{~K}_{90}$.

Систематическое применение органических, минеральных удобрений и известкование увеличивает количество подвижных форм питательных веществ, степень их подвижности и доступность для растений. В результате улучшается плодородие почвы, повышается урожайность и качество зерна яровой пшеницы.

\section{Литература}

1. Агрохимия / под ред. П.М. Смирнова, А.В. Петербургского. М. : Колос, 1975.512 c.

2. Бережная В.В., Кушаева Е.Ж., Тимошинов Р.В., Клыков А.Г. Влияние различных доз удобрений на урожайность яровой пшеницы на лугово-бурых отбеленных почвах Приморского края // Роль аграрной науки в развитии лесного и сельского хозяйства Дальнего Востока : материалы II Национальной (Всероссийской) науч.-практич. конф. / Примор. ГСХА. Уссурийск, 2018. Ч. І. С. 59-64. 
3. Гаврилюк Ф.Я. Методологические основы бонитировки почв // Научные основы рационального использования почв Северного Кавказа и пути повышения их плодородия. - Нальчик, 1971. С. 30-33.

4. Гаврилюк Ф.Я. Мощность и запасы гумуса в почвах - показатель плодородия черноземов и каштановых почв Нижнего Дона и Северного Кавказа // Биологические науки. 1972. № 11. С. 123-125.

5. Гамзиков Г.П. Состояние и перспективы исследований в длительных стационарных опытах с удобрениями в Сибири // Плодородие. 2016. № 5 (92). С. 6-9.

6. Грицун А.Т. Применение удобрений в Приморском крае. Владивосток, 1964. $440 \mathrm{c}$.

7. Грицун А.Т., Васичева А.Д., Аксенов А.А. Агрохимическая характеристика почв Приморского края // Агрохимическая характеристика почв СССР. Дальний Восток. М. : Наука, 1971. С. 31-46.

8. Державин Л.М., Фрид А.С. О комплексной оценке плодородия пахотных земель // Агрохимия. 2001. № 9. С. 5-12.

9. Дмитриев Н.Н., Гамзиков Г.П. Систематическое применение удобрений как фактор стабилизации плодородия серых почв и продуктивности зерновых культур в зернопаровом севообороте // Агрохимия. 2015. № 2. С. 3-12.

10. Доспехов Б.А. Методика полевого опыта (с основами статистической обработки результатов исследований). М.: Альянс, 2014. 351 с.

11. Моисеенко А.А., Хасбиулина Р.Г. Изменение плодородия луговобурых почв и урожайности сельскохозяйственных культур при длительном применении удобрений в полевом севообороте // Аграрная наука - сельскохозяйственному производству Дальнего Востока : сб. науч. тр. / РАСХН, ДВ НМЦ, Примор. НИИСХ. Владивосток : Дальнаука, 2005. С. 187-192.

12. Моисеенко А.А., Хасбиулина Р.Г. Последействие длительного применения различных систем удобрений в севообороте // Земледелие. 2006. № 6. С. 13-14.

13. Моисеенко А.А., Хасбиулина Р.Г., Кушаева Е.Ж. Продолжительность последействия удобрений на урожайность культур в севообороте // Пути повышения ресурсного потенциала сельскохозяйственного производства Дальнего Востока : сб. науч. тр. / РАСХН, ДВ НМЦ, Примор. НИИСХ. Владивосток : Дальнаука, 2007. С. 372-375.

14. Моисеенко А.А., Хасбиуллина Р.Г. Изменение продуктивности севооборота и свойств почвы в результате длительного применения раз- 
ных систем удобрений в условиях Приморского края. Тимирязевский, 2006. 44c.

15. Рабинович Г.Ю., Смирнова Ю.Д., Лукичева Н.А. Возделывание яровой пшеницы с применением различных схем удобрений // Использование мелиорированных земель - современное состояние и перспективы развития мелиоративного земледелия : междунар. науч.-практич. конф. / ВНИИМЗ. Тверь : ВНИИМЗ, 2015. С. 33-37.

16. Романенко Г.А., Тютюнников А.И., Сычев В.Г. Удобрения. Значение, эффективность применения : справочное пособие. М., 1998. 376 с.

17. Синельников Э.П. Почвоведение : учебно-метод. рекомендации. Уссурийск, 2013. 66 с.

18. Синельников Э.П., Слабко Ю.И. Агрогенезис почв Приморья. М. : ВНИИА, 2005. $280 \mathrm{c.}$

19. Слабко Ю.И., Синельников Э.П. К проблеме оценки плодородия пахотных земель [Электронный ресурс]. URL: http://www.agbz.ru/articles/kprobleme-otsenki-plodorodiya-pahotnyih-zemel (дата обращения 03.05.2018).

20. СТП 2529001383-96. Почвы. Методика оценки плодородия почв Приморского края на основе показателей почвенно-агрохимического обследования. Введ. 01.01.96. Тимирязевский, 1996. 12с.

21. Тимошинов Р.В., Кушаева Е.Ж., Бабинец Л.Е., Фалилеев А.А., Юленкова Л.В. Влияние различных систем удобрений на урожайность и качество зерна яровой пшеницы сорта Приморская 39 // Аграр. вестн. Приморья. 2018. № 4 (12). С. 13-17.

22. Федоров А.А. Система применения удобрений. Уссурийск : ПГСХА, 1998. 167c.

23. Хасбиулина Р.Г., Моисеенко А.А., Кушаева Е.Ж. Агрохимические свойства и продуктивность лугово-бурых почв при последействии удобрений // Дальневост. аграр. вестн. 2009. Вып.1 (9). С. 11-14.

24. Ягодин Б.А., Жуков Ю.П., Кобзаренко В.И. Агрохимия. М. : Колос, 2002. 584 с.

25. Mudahar M.S., Hignett T.P. Energy efficiency in nitrogen fertilizer production // Energy Agric. 1980. 4. P. 159-177.

26. Niehoff K. Auf winterroggen in der Fruchtfolge nisht verzichen // Wochenblatt. 1981. 35. P. 23.

27. Soon Y.K. Nutrients uptake by barbey roots under field conditions // Plant Soil. 1988. 109(2). P. 171-179. 